\title{
References:
}

1. Volman B. L. (1980). Hitara [Guitar]. Moskva : Muzyka. (Issue 2) [in Russian].

2. Hrynenko S. M. (2018). Riznovydy akustychnoi hitary ta yikh zastosuvannia v suchasnii muzychnii kulturi [Varieties of acoustic guitar and their application in contemporary music culture]. Ukrainska kultura: mynule, suchasne, shliakhy rozvytku - Ukrainian culture: past, present, ways of development, 26. 163-167 [in Ukrainian].

3. Mihajlenko N. P., Fan Din' Tan. (1998). Spravochnik gitarista [Guitarist Handbook]. Kiev : Fan's company [in Ukrainian].

4. Niprokin Ju. (2002). Jetjudy o gitaristah [Etudes about guitarists]. Odesa : Druk [in Ukrainian].

5. Rozina O. F. (2014). Bazova struktura poiednannia tantsiu, vokalu y hitary v riznykh styliakh flamenco [The basic structure of the combination of dance, vocals and guitars in different flamenco styles] Kultura Ukrainy - Culture of Ukraine. Kharkiv : KhDAK, 45. 165-174 [in Ukrainian].

6. Rozina O. F. (2012). Flamenko yak symbioz muzychno-tantsiuvalnykh tradytsii skhodu i zakhodu. [Flamenco as a symbiosis of East and West music and dance traditions]. Kultura Ukrainy - Culture of Ukraine. Kharkiv : KhDAK, 38. 158-166 [in Ukrainian].

7. Sharnasse Je. (1991). Shestistrunnaja gitara (ot istokov do nashih dnej) [Six-string guitar (from the beginnings to the present day)]. (S. Kudrjavickoj, Trans). Moskva : Muzyka [in Russian].

8. Shevchenko A. A. (1988). Hitara flamenko: melodii ta rytmy [Flamenco Guitar: Melodies and Rhythms]. Kyiv : Muzychna Ukraina [in Ukrainian].

9. Shevchenko A. A. (2004). Etnohrafiia hitary [Ethnography of guitar]. Arkadiia-Arcadia. Kherson : FOP Hrin D. S., 2. 11-12 [in Ukrainian].

10. Shevchenko A. A. (1980). Nevpokoreni ihry flamenko [Unconquered flamenco games]. Muzyka - Music. Kyiv : Muzychna Ukraina, 5. 22-23 [in Ukrainian].

11. Shevchenko A. A. (2008). Formuvannia hitary v konteksti zahalnoho protsesu rozvytku muzychnoi kultury [Guitar formation in the context of the general process of musical culture development]. Problemy vzaiemodii mystetstva, pedahohiky ta teorii i praktyky osvity "Hitara yak zvukovyi obraz svitu: vykonavske mystetstvo ta nauka» - Problems of interaction between art, pedagogy and theory and practice of education 'Guitar as a sound image of the world: performing arts and science», 23. 5-9 [in Ukrainian].

\section{Kovalenko A. S. The role of flamenco in the development of guitar education in Ukraine}

The article provides a historiographical analysis of the origins of flamenco art in Ukraine and its impact on the development of national guitar education. Applying the methods of historical-pedagogical analysis and systematic approach, the scientific works of leading scientists of the field are considered.

It is determined that flamenco is an art that, by combining elements of cultures of other peoples, formed its own original structure: vocals, choreography and guitar accompaniment. It is proved that this phenomenon, having formed in Spain, quickly became widespread in the world and Ukrainian space in particular. It has been determined that in the days of flamenco art the technique of the guitarist was quite primitive, but with the beginning of the era of «cafe cantante» the role of the guitar increased significantly and the technique was improved accordingly.

Contemporary flamenco guitarists accompanying singing and dancing - they improvise perfectly, despite the fact that they usually do not have an academic music education. The virtuosity required in the performance of some of the pieces makes it easy for the guitarist to move from accompaniment to solo play. Flamenco's native art was developed and multiplied by A. Shevchenko. The works he wrote for the guitar expanded the repertoire of Ukrainian guitarists and enriched their expressive capabilities.

For classical guitarists, studying flamenco music will allow you to expand your understanding of the use of some performing techniques and enhance the performance of performing techniques. It has been determined that domestic guitar education will win if the educational program includes: works written in the flamenco style, a course on the basics of improvisation, discipline "Methodology for guitarists», which will cover the technology of mastering the art of flamenco in the guitar class.

Key words: flamenco, guitar art, domestic guitar education, guitar school, music education, guitar performers, guitar composers, performing on the guitar.

УДК 37.015.3:159.923.4 (477.82) (045)

DOI https://doi.org/10.31392/NPU-nc.series5.2019.71.32

Козігора М. A.

\section{ВПЛИВ ТЕМПЕРАМЕНТУ МОЛОДШОГО ШКОЛЯРА НА УСПІШНІСТЬ НАВЧАЛЬНОЇ ДІЯЛЬНОСТІ}

У статті розглянуто основні аспекти прояву темпераменту під час навчальної діяльності та його вплив на успішність. Серед рис, які визначають нашу індивідуальність ми зупинилися детальніше на вроджених і тих, які проявляються в так званих властивостях темпераменту.

Якщо спостерігати за людьми, то можна побачити, щзо вони відрізняються один від одного своєю поведінкою: по-різному проявляють свої почуття, неоднаково реагують на подразники зовнішнього середовища. Так, одні вирізняються врівноваженістю поведінки, діють обмірковано, не показують зовні свойх почуттів, інші за тих самих обставин нервуються, емоиійно збуджуються та вибухають вулканом почуттів з приводу незначних подій. Одні комунікабельні, легко вступають у контакти з людьми, життєрадісні, а інші, навпаки, замкнуті та стримані. I ие стосується суто зовнішніх проявів, незалежно від того, наскільки ияя людина розумна, пращелюбна, смілива, які їі прагнення та інтереси. 
Такі індивідуальні особливості мають назву «темперамент» (від лат. tетрегатепtит - належне співвідношення частин). Темперамент - вроджена (біологічно зумовлена) і майже незмінна властивість людської психіки, що визначає реакиію людини на інших людей та на обставини. Темперамент становить основу розвитку характеру.

У системі неперервної освіти початкової школи покладені важливі функиї, успішне виконання яких безпосередньо виливає на якість подальшої освіти учнів. Індивідуальні особливості особистості й особливості темпераменту є засобами реалізації внутрішнього потенціалу школяра у навчальній діяльності діяльності.

Аналіз психолого-педагогічної літератури та практика роботи школи засвідчили, щуо такий важливий аспект, як вплив темпераменту на формування індивідуального стилю учбової діяльності, та вплив ї на успішність навчання молодших школярів не став предметом спеиіального дослідження, разом з тим, можна сказати, щзо вчителі початкових класів мають потребу в науково обтрунтованих рекомендаціях у иій галузі.

Ключові слова: темперамент, школяр, успішність, навчальна діяльність, індивідуальні особливості, характер, раннє дитинство, молодиий шкільний вік.

Молодшим шкільним віком прийнято вважати вік дітей від 6-7 до 10-11 років, що відповідає рокам їх навчання в початкових класах. Це вік спокійного і рівномірного фізичного розвитку.

Збільшення росту і ваги, витривалості йдуть досить рівномірно і пропорційно. Кісткова система молодшого школяра ще знаходиться в стадії формування - окостеніння хребту, грудної клітки, таза, кінцівок ще не довершено, у кістковій системі ще багато хрящової тканини.

Відбувається функціональне удосконалювання мозку - розвивається аналітико-систематична функція кори; поступово змінюється співвідношення процесів порушення і гальмування: процес гальмування стає усе більш сильним, хоча як і раніше переважає процес порушення, і молодші школярі у високому ступені збудливі й імпульсивні.

Прихід до школи вносить найважливіші зміни в життя дитини. Різко змінюється весь уклад іiі життя, іiі соціальний стан у колективі, родині. Основною, ведучою діяльністю стає відтепер навчання, найважливішим обов'язком - обов'язок учитися, здобувати знання. А навчання - це серйозна праця, що вимагає організованості, дисципліни, вольових зусиль дитини. Школяр включається в новий для нього колектив, у якому він буде жити, учитися, розвиватися цілих 11 років.

Молодший шкільний вік - це період найбільш інтенсивного формування учбової діяльності. Все, що пов'язане з грою, для школяра стає менш значущим, ніж те, що пов'язане з учбовою діяльністю, яка стає провідним видом діяльності [5, с. 67].

Молодший шкільний вік характеризується певними психологічними віковими особливостями:

- перебудова пізнавальних процесів - формування довільності;

- розвиток саморегуляції поведінки, волі;

- засвоєння вмінь читання, письма, обчислень, накопичення знань;

- розширення сфери спілкування;

- формування самооцінки;

- формування впевненості в собі, компетентності;

- формування зневіри у власних силах, втрата інтересу до навчання.

У розвитку кожної людини виявляється загальне й особливе. Загальне властиве всім людям певного віку; особливе вирізняє окрему людину. Особливе в людині називають індивідуальним, а особистість 3 яскраво вираженим особливим - індивідуальністю.

- Індивідуальність характеризується сукупністю інтелектуальних, вольових, моральних, соціальних та інших рис людини, які постійно вирізняють одну людину від інших людей.

- До індивідуальних особливостей належать своєрідність відчуттів, сприймання, мислення, пам'яті, уяви, особливості інтересів, нахилів, здібностей, темпераменту, характеру особистості [4, с. 89].

Основною діяльністю, його першим і найважливішим обов'язком стає навчання - придбання нових знань, умінь і навичок, нагромадження систематичних відомостей про навколишній світ, природу і суспільство.

Зрозуміло, далеко не відразу в молодших школярів формується правильне відношення до навчання. Вони поки не розуміють навіщо потрібно учитися. Але незабаром виявляється, що навчання - праця, що вимагає вольових зусиль, мобілізації уваги, інтелектуальної активності, самообмежень. Якщо дитина до цього не звикла, то в неї настає розчарування, виникає негативне відношення до навчання. Для того, щоб цього не трапилося вчитель повинен вселяти дитині думку, що навчання - не свято, не гра, а серйозна, напружена робота, однак дуже цікава, тому що вона дозволить довідатися багато нового, цікавого, важливого, потрібного. Важливо, щоб і сама організація навчальної роботи підкріплювала слова вчителя.

Навчальна діяльність у початкових класах стимулює, насамперед, розвиток психічних процесів безпосереднього пізнання навколишнього світу відчуття і сприйняття. Молодші школярі відрізняються гостротою і свіжістю сприйняття, свого роду споглядальною допитливістю. Молодший школяр з живою цікавістю сприймає навколишнє середовище, що з кожним днем розкриває перед ним усе нові і нові сторони.

Молодші школярі дуже емоційні. Емоційність позначається, по-перше, в тому, що їхня психічна діяльність зазвичай зафарбована емоціями. Усе, що діти спостерігають, про що думають, що роблять, викликає в них емоційно-забарвлене відношення. По-друге, молодші школярі не вміють стримувати свої почуття, контролювати їх зовнішній прояв, вони дуже безпосередні і відверті у вираженні радості, горя, суму, страху, 
задоволення чи невдоволення. По-третє, емоційність виражається в їхній великій емоційній нестійкості, частій зміні настроїв, схильності до афектів, короткочасним і бурхливим проявам радості, горя, гніву, страху. 3 роками усе більше розвивається здатність регулювати свої почуття, стримувати їхні небажані прояви.

Кожній дитині притаманні індивідуальні властивості нервової системи, темперамент, інтереси, здібності, особливості мислення, уяви, пам'яті, емоцій, воля, активність, темп роботи, швидкість засвоєння навичок тощо. Цілий ряд відмінностей формуються у людини протягом життя, але особливості, до яких належать типологічні риси вищої нервової діяльності - темперамент.

Темперамент - сукупність індивідуальних особливостей, які характеризують динаміку та емоційну сторони поведінки людини, іiі діяльності та спілкування.

Залежність успішності молодшого школяра від типу темпераменту полягає в типологічній зумовленості цих характеристик. 3в'язок особливостей індивідуального стилю діяльності з властивостями нервової системи досліджувався у працях Г. С. Дикопольської, О. О. Копитова, А. О. Коротаєва, Є. О. Климова та С. І. Маствіліскер.

Темперамент відбиває динамічні аспекти поведінки, переважно вродженого характеру, тому властивості темпераменту найбільш стійкі і постійні в порівнянні з іншими психічним особливостями людини. Найбільш специфічна особливість темпераменту полягає в тому, що різні властивості темпераменту даної людини не випадково поєднуються один з одним, а закономірно зв’язані між собою, утворюючи певну організацію, структуру, що характеризує темперамент.

Для того щоб побудувати індивідуальний підхід до кожної дитини та забезпечити для його розвитку відповідні психологічні умови, педагогам потрібні знання характерних особливостей поведінки дітей залежно від типу їх темпераменту.

Темперамент визначається при цьому не однією якою-небудь властивістю нервової системи, а їх поєднанням. Враховуючи це, І. П. Павлов, об'єднавши в групи відповідні властивості, назвав їх типом нервової системи і виділив 3 них основні: сильний урівноважений рухливий, сильний урівноважений інертний, сильний неврівноважений (з домінуванням процесу збудження), слабкий [3, с. 90].

Особливості типу темпераменту починають проявлятися вже з раннього дитинства. Завдання вчителів враховувати особливості того чи іншого типу темпераменту в навчальній діяльності. Але це не означає, що кожна людина може віднести себе до одного з перелічених типів темпераменту в його чистому вигляді, оскільки такий темперамент зустрічається в житті досить рідко і швидше в дитячому віці.

Якщо в характері дитини виявлені й домінують риси того чи іншого типу темпераменту, його відносять до одного з чотирьох зазначених типів [3, с. 90].

Результативність освітнього процесу значною мірою залежить від врахування індивідуальних особливостей характеру кожного учня.

Урахування індивідуальних особливостей молодших школярів у навчанні та вихованні - це не пристосовування мети і змісту навчання і виховання до окремого учня, а пристосовування прийомів, методів і форм педагогічного впливу до індивідуальних їх особливостей з метою забезпечення запрограмованого рівня розвитку особистості. Індивідуальний підхід створює найсприятливіші можливості для розвитку пізнавальних можливостей, активності, схильності кожного учня.

Такого підходу потребують насамперед діти, які виявляють неадекватну поведінку, обмежені, нерозвинені здібності, мають чітко виражені відхилення в розвитку [7].

Плутарх говорив : «Якими діти народжуються, це ні від кого не залежить, але щоб вони завдяки правильному вихованню стали хорошими - це в наших силах».

Отже, врахування індивідуально-типологічних особливостей учнів у навчанні та вихованні - це не пристосування мети і змісту навчання і виховання до окремого учня, а пристосування прийомів, методів і форм педагогічного впливу до індивідуальних особливостей з метою забезпечення запрограмованого рівня розвитку особистості.

Особистісно-зорієнтований підхід створює найсприятливіші можливості для розвитку пізнавальних сил, активності, схильностей і обдарувань кожного учня. Такого підходу потребують насамперед важкі вихованці, малоздібні школярі, а також діти з чітко вираженою затримкою розвитку [2, с. 280].

Отже, проаналізувавши наукову літературу з даної проблеми можемо стверджувати про те, що особливості темпераменту суттєво впливають на навчальну діяльність молодших школярів, специфіку використання ними способів та прийомів розумової діяльності.

Роль темпераменту в діяльності полягає в тому, що від нього залежить ступінь та характер впливу на діяльність як зовнішніх умов, так і внутрішніх - тобто індивідуально-психологічних властивостей людини. Тому одним 3 шляхів пристосування темпераменту до вимог діяльності є формування індивідуального стилю діяльності.

Особливості типу темпераменту починають проявлятися вже з раннього дитинства. Завдання вчителів та вихователів полягає в тому, щоб зважати на ці особливості та виробляти у дітей уміння володіти своїм темпераментом.

Діти із сангвінічним темпераментом характеризуються легкою збудливістю почуттів. Діти цього темпераменту швидкі й рухливі, але меншою мірою, ніж сангвініки дорослі. 
Оскільки в дітей сангвінічного темпераменту легко утворюються та залишаються стійкими тимчасові зв'язки, вони легко засвоюють новий матеріал, майже «хапають на льоту». Але оскільки вони дуже рухливі і їхня увага відволікається від основної справи, до них слід застосовувати заходи, які б виховували посидючість та зосередженість. Потрібно постійно підтримувати інтерес сангвініків до розпочатої справи, інакше вони почнуть нудьгувати, стануть млявими або, навпаки, шукатимуть сторонні збудники та розважатимуться - говорить О. В. Скрипченко [2, с. 54].

Діти холеричного темпераменту характеризуються легкою збудливістю почуттів, силою й стійкістю їх у часі. За правильних умов виховання ці діти виявляють активність і наполегливість у роботі, а за неправильних - стають неслухняними, запальними, образливими.

Працюючи з холериками, слід ураховувати, що вони легко концентрують свою увагу на тому чи іншому об’єкті, але не можуть iї швидко переключити, так як процеси гальмування в них уповільнені. Вчителям слід так організовувати діяльність учнів, щоб полегшити успішне переключення уваги та виховувати уміння ії переключати [1, с. 85].

Холерики також схильні до порушення дисципліни на уроках, тому що частіше бувають підвищено збудливими, схильними до афективних реакцій, їх треба захопити цікавими справами і давати якісь доручення. Навички та звички у холерика утворюються швидко, але змінити їх буває дуже і дуже важко. Тому перехід від звичних дій до інших, нових, має здійснюватися поступово. Неврівноважені діти (якими є холерики) потребують більше часу для утворення нового динамічного стереотипу - тому до них не можна використовувати грубих, категоричних заборон, а спрямовувати на іншу діяльність поступово.

У дітей флегматичного темпераменту почуття важко збуджувані, однак тривалі і стійкі. Молодший школяр-флегматик повільний, він здебільшого неохоче спілкується, часто нехтує справами, що вимагають від нього швидкості, турбот, зайвих рухів. Дитина-флегматик ухиляється від конфліктів, іiі важко образити, але коли вступає в конфлікт, то переживає глибоко, хоч зовні це не виявляється так яскраво, як у дітей вищезгаданих типів.

Діти 3 меланхолійним темпераментом надзвичайно чутливі, почуття в них виникають легко, вони міцні й стійкі в часі. Такі діти здебільшого сором'язливі, малоактивні, важко пристосовуються до нових обставин. Вони часто розгублюються при опитуванні, хоч і мають хороші знання.

У дітей флегматичного та меланхолічного темпераментів тимчасові зв'язки утворюються повільніше внаслідок недостатньої рухливості кіркових процесів. Тому їм потрібно давати більше часу на засвоєння та опанування навчального матеріалу [6, с. 79].

Інертність нервових процесів, недостатня рухливість флегматиків призводить до того, що вони повільно переключають увагу. Працюючи з ними, слід добирати завдання, які сприяють виробленню більшої швидкості реагування та моторної рухливості. Динамічні стереотипи у флегматиків утворюються повільніше, ніж у сангвініків, а тому їх треба поступово переключати з однієї звичної дії на іншу [6, с. 35]

Діти меланхолічного темпераменту потребують особливої уваги внаслідок своєї вразливості, швидкої втомлюваності організму, їм необхідні спокійне, сприятливе оточення та продуманий режим впливу, який передбачає поступовий перехід від звичних умов життя до іншої діяльності та обставин. Слабкість нервових процесів цих учнів вимагає чутливого та обережного ставлення, продуманих методів педагогічного впливу.

Роль темпераменту в діяльності полягає в тому, що від нього залежить ступінь та характер впливу на діяльність як зовнішніх умов, так і внутрішніх - тобто індивідуально-психологічних властивостей людини. Тому одним 3 шляхів пристосування темпераменту до вимог діяльності є формування індивідуального стилю діяльності.

Темперамент характеризує психічну індивідуальність дитини насамперед з боку властивої їй динаміки нервово-психічних процесів і станів, їхньої інтенсивності, швидкості, ритму, тривалості, перебігу.

Уже на початку навчання в школі учні відрізняються один від одного рівнем обізнаності 3 навколишнім світом, спостережливістю, вмінням думати, запам'ятовувати й відтворювати, висловлювати свої думки за допомогою усного мовлення та ін.

Своєрідність молодшого шкільного віку полягає в тому, що особливості дитини вже сформовані, а достатнього життєвого досвіду для даної (учбової) діяльності ще немає.

Саме це дає змогу простежити зародження індивідуального стилю учбової діяльності, визначити такі завдання, в яких виявилися б найбільш характерні реакції, пов'язані з типом вищої нервової діяльності й темпераменту, змоделювати умови, потрібні для нагромадження знань, умінь та навичок, що необхідні для розв'язання певних завдань.

Використана література:

1. Белоус В.В. Темперамент и деятельность: учеб. пособие / В.В. Белоус. - Пятигорск, 1990. - 328 с.

2. Вікова та педагогічна психологія: навч. посіб. / О.В. Скрипченко, Л.В. Долинська, З.В. Огороднійчу та ін. - К. : Просвіта, 2001. $-416 \mathrm{c}$.

3. Вітенко I.С., Вітенко T.І. Основи психології / I.С. Вітенко, Т.І. Вітенко. - 2-е вид., переробл. і доп. - Вінниця : НОВА КНИГА, 2008. - $256 \mathrm{c.}$

4. Зайченко І.В. Педагогіка. Навчальний посібник для студентів вищих педагогічних навчальних закладів / I.В. Зайченко. 2-е вид. - К. : «Освіта України», «КНТ», 2008. - 528 с. 
5. Кутішенко В.П. Вікова та педагогічна психологія (курс лекцій): навч. посіб. / В.П. Кутішенко. - 2-ге вид. - К.: Центр учбової літератури, 2010. - 128 с.

6. Русалов В.М. О природе темперамента и его месте в структуре индивидуальних свойств человека / В.М. Русалов // Вопросы психологии. - 1985. - № 11. - С. 35-79.

7. Шадських Ю.Г.Психологія і педагогіка: навч. посіб. для студ. вищих навч. Закладів/ Ю.Г. Шадських. -Львів : Магнолія. 2006. $-319 \mathrm{c}$.

1. Belous, V. V. (1990). Temperament y deiatelnost [Temperament and activity]. Piatyhorsk [in Ukrainaian].

2. Skrypchenko, O.V., Dolynska, L.V.,Ohorodniichu, Z.V. etal. (2001). Vikova ta pedahohichna psykholohiia [Age and pedagogical psychology]. Kyiv : Prosvita [in Ukrainaian].

3. Vitenko, I.S., \& Vitenko, T.I. (2008). Osnovy psykholohii. [Fundamentals of psychology] (2nd ed., rev.). Vinnytsia: NOVA KNYHA [in Ukrainaian].

4. Zaichenko, I.B. (2008). Pedahohika. [Pedagogy] (2nd ed.). Kyiv : «Osvita Ukrainy», «KNT», [in Ukrainaian].

5. Kutishenko, V.P. (2010). Vikova ta pedahohichna psykholohiia (kurslektsii) [Ageand Pedagogical Psychology (LectureCourse)] (2nd ed.). Kyiv Tsentr uchbovoi literatury [in Ukrainaian].

6. Rusalov, V.M. (1985). O pryrode temperamenta y eho meste v strukture yndyvydualnykh svoistv cheloveka [On the nature of temperament and its place in the structure of individual human properties]. Voprosy psykholohyy - Psychology issues, 11, 35-79 [in Ukrainaian].

7. Shadskykh, Yu.H. (2006). Psykholohiia i pedahohika [Psychology and pedagogy]. Lviv : Mahnoliia [in Ukrainaian].

\section{Kozihora M. A. The influence of the younger pupils' temperament on the success of educational activity}

The article deals with the main aspects of temperament manifestation during learning activities and its impact on academic performance. Among the traits that determine our personality, we focus in more detail on the innate and those that manifest themselves in the so-called properties of temperament.

If we observe people, we can see that they differ from each other in their behavior: in different ways they express their feelings, react unequally to environmental stimuli. Yes, some differ in behavior, act deliberately, do not show their feelings outwardly, others under the same circumstances are nervous, emotionally excited and explode by a volcano of feelings about minor events. Some are sociable, easy to get in touch with, cheerful, and others, conversely, closed and restrained. And this applies only to outward manifestations, no matter how smart, hardworking, courageous, their aspirations and interests are.

Such individual features are called "temperament" (from the Latin. Temperamentum - the proper ratio of parts). Temperament is the innate (biologically conditioned) and almost invariable property of the human psyche, which determines a person's response to other people and circumstances. Temperament is the basis of character development.

In the system of continuing education of elementary school important functions are laid, the successful implementation of which directly affects the quality of further education of students. Individual personality traits and temperament features are the means of realizing the inner potential of the student in the educational activity of the activity.

The analysis of the psychological and pedagogical literature and the practice of the school work showed that such an important aspect as the influence of temperament on the formation of individual style of educational activity, and its influence on the success of teaching the younger students was not the subject of special study, however, we can say that elementary teachers classes need science-based guidance in this area.

Key words: temperament, schoolboy, academic achievement, educational activity, individual characteristics, character, early childhood, younger school age.

УДК 378.4: 614

DOI https://doi.org/10.31392/NPU-nc.series5.2019.71.33

Корже Г. I.

\section{ПЕДАГОГІЧНІ УМОВИ РОЗВИТКУ ЦІННІСНОГО СТАВЛЕННЯ ДО ЗДОРОВ'Я В МАЙБУТНІХ ФАХІВЦІВ ЦИВІЛЬНОЇ БЕЗПЕКИ}

Обгрунтовано актуальність проблеми розвитку иіннісного ставлення до власного здоров'я у фахівців циивільної безпеки. Проведено аналіз стану наукової розробки проблеми розвитку иіннісного ставлення до здоров'я в майбутніх фахівиів. Наголошено на ключовій ролі освіти у формуванні ичіннісного ставлення до власного здоров'я в студентської молодi.

Представлено термінологічне значення понять «иіннісне ставлення до здоров'я» та «педагогічні умови». На підставі теоретичного аналізу наукових прачь автором визначено і теоретично обтрунтовано такі педагогічні умови формування иіннісного ставлення до здоров'я: розвиток стійкої мотиваиії в майбутніх фахівців до збереження $i$ зміинення здоров'я та створення освітнього середовища, сприятливого до здоров'я усіх учасників освітнього процесу.

Виокремлено та розкрито зміст підходів до формування мотивів, переконань і потреб у ціннісному ставленні до здоров'я і здоровому способі життя в майбутніх фахівиів ициільної безпеки. Підкреслено роль здоров'язберігаючого освітнього середовища як системи чинників, щуо впливають на формування особистості майбутнього фахівия, активізацію його самопізнання і саморозвитку. Розкрито структурні компоненти иього середовища: змістовнотехнологічний, матеріально-технічний та соиіальний. Для реалізації визначеної мети обтрунтовано застосування здоров'язберігаючих освітніх технологій, які детермінують формування соціальної зрілості в майбутніх фахівців, надають можливість реалізувати свій потенціал і при цььому зберегти і зміцнити власне здоров'я. 